\title{
Research on Efficiency of Listed Commercial Banks in China Based on SBM
}

\author{
Xiping Wang \\ School of Economics and Management, North China Ele- \\ ctric Power University \\ Baoding, Hebei, China \\ 071051 \\ 954419367@qq.com
}

\author{
Xulei Wang \\ School of Economics and Management, North China Ele- \\ ctric Power University \\ Baoding, Hebei, China \\ 071051 \\ 824767366@qq.com
}

\begin{abstract}
For the purporse of accurately caclulating the banking efficiency of China in recent years, a slack-based measure (SBM) was used to measure the relative efficiency of 16 listed commercial banks considering the non-performing loans over the period of 2007-2012. Staff costs, total loans and fixed assets were chosen as the inputs, whereas net profit and non-performing loans were outputs in this study. The results show that the city commercial bank efficiency is the highest, joint-stock banks are more efficent than large state-owned commercial banks. Further study indicates that staff costs and bad loans are the main sources of banking inefficiency. Finally, the interbank competition not only reflected on the competetion with money and customer resources, but also on the reducing the risk of bank assets and enhancing the efficiency of commercial banks.
\end{abstract}

Keywords-commercial banks; SBM directional distance function; non-performing loans

\section{INTRODUCTION}

Commercial banks act as the main body of China's financial system, which efficiency reflect the allocation of overall resources. The accurate measurement and evaluation to the efficiency of commercial banks can not only explore the inefficiency of commercial banks, probe the ways to improve the bank efficiency, but also has very important significance on improving the competitiveness of banking, keeping the financial system healthy and sustainable development as well.

Since 1950s, the domestic and foreign scholars have conducted a lot of research on commercial bank efficiency, and developed scale-efficiency, scope-efficiency and frontierefficiency. Farrel (1957) first introduced frontier production function to evaluate the resource utilization rate and the production efficiency. Sherman (1985) used the DEA method to measure bank efficiency firstly. Yang (1999) investigated the efficiency by using the method of DEA in a Chinese Commercial Bank branches, the scale efficiency and technical efficiency of the state-owned commercial banks are increasing. Cai and Guo (2009) suggest that 11 listed commercial banks efficiency decreased slightly for the period 2004-2008, among them, dropped index of technological change has relation with the macro-control, monetary, credit policy; the reform of shareholding system is helpful to improve the efficiency of commercial banks. Unfortunately, there's a flaw in those literatures that no non-performing loans as an unwilling indicator to considered, meaning only considered the loan quantity and ignored the loan quality, which leading a deviation measure to bank efficiency. Zhang, Chi and $\mathrm{Wu}$ (2006) introductd the non-performing loans as the output factor into the DEA model firstly, calculated the restricting factors of bank efficiency. Chung (1997) proposed the directional distance function, because it considered the increase in willing outputs and the reduce in unwilling outputs, then put the "good" and "bad" outputs into the same framework properly, provides a good choice for efficiency measurement. Wang and Zhu (2011) measured the efficiency of Chinese 27 commercial banks considering the non-performing loans for the period 2004-2009, the result showed that, technology efficiency gap deviates from the common boundary, state-owned banks showed "V" type, commercial banks are stable, city commercial banks rise gradually.

Chung (1997) proposed the directional distance function is the DEA model essentially, it assumes that the input and output, willing output and unwilling output vary by the same proportion, however, when there has excessive input or output deficiency, the radial DEA model will overestimate the efficiency. Therefore, this paper introduced the non-radial SBM directional distance function, in order to calculate the efficiency of 16 listed commercial banks and decompose the inefficiency.

\section{METHODOLOGY AND DATA}

\section{A. Model Construction}

Data envelopment analysis (DEA) is an approach for measuring the relative efficiency of peer decision making units (DMUs) that have multiple inputs and outputs. The traditional DEA model was proposed by Charnes, Cooper and Rhodes (1978), which applied an optimal linear programming formula to calculate efficiency of DMUs. Suppose that each bank is a decision making unit, each DMU has 3 vectors: input, willing output and unwilling output. We define matrix $\mathrm{X}, \mathrm{Y}$ and $\mathrm{B}$ as follows: each bank has $\mathrm{N}$ inputs $X=\left(x_{1}, x_{2} \cdots, x_{N}\right) \in R_{+}^{N}$, get the willing $\mathrm{M}$ output $\mathrm{Y}=\left(y_{1}, y_{2}, \cdots, y_{M}\right) \in R_{+}^{M}$, and the unwilling I output $B=\left(b_{1}, b_{2} \cdots, b_{I}\right) \in R_{+}^{I}$. Based on the DEA model the efficiency scores can be calculated as the following models: 


$$
\begin{aligned}
& P^{t}\left(x^{t}\right)=\left\{\left(y^{t}, b^{t}\right): \sum_{k=1}^{K} \lambda_{k}^{t} y_{k m}^{t} \geq y_{k m}^{t}, \forall m ; \sum_{k=1}^{K} \lambda_{k}^{t} b_{k i}^{t}=b_{i}^{t}, \forall i ;\right. \\
& \left.\sum_{k=1}^{K} \lambda_{k}^{t} x_{k n}^{t} \leq x_{n}^{t}, \forall n ; \sum_{k=1}^{K} \lambda_{k}^{t}=1, \lambda_{k}^{t} \geq 0, \forall k\right\}
\end{aligned}
$$

Where $\lambda_{k}^{t}$ is the weight of each sample bank observations, when the sum is 1 , represents the variable returns to scale (VRS); if the removed the weight, it becomes constant retums to scale (CRS).

According to Fukuyama and Weber (2009), we defined the SBM directional distance function as follow:

$$
\begin{aligned}
& \overrightarrow{S_{V}^{t}}\left(x^{t, k^{t}}, y^{t, k^{t}}, b^{t, k^{t}} ; g^{x}, g^{y}, g^{b}\right)=\underset{s^{t}, s^{a}, s^{b}}{\operatorname{Max}} \frac{\frac{1}{N} \sum_{n=1}^{N} \frac{s_{n}^{x}}{g_{n}^{x}}+\frac{1}{M+I}\left[\sum_{m=1}^{M} \frac{s_{m}^{y}}{g_{m}^{y}}+\sum_{i=1}^{I} \frac{s_{i}^{b}}{g_{i}^{b}}\right]}{2} \\
& \text { s.t. } \sum_{k=1}^{K} \lambda_{k}^{t} x_{k n}^{t}+s_{n}^{x}=x_{k n}^{t}, \forall n ; \sum_{k=1}^{t} \lambda_{k}^{t} y_{k m}^{t}-s_{m}^{y}=y_{k m}^{t}, \forall m ; \sum_{k=1}^{K} \lambda_{k}^{t} b_{k i}^{t}+s_{i}^{b}=b_{k i}^{t}, \forall i ; \\
& \sum_{k=1}^{K} \lambda_{k}^{t}=1, \lambda_{k}^{t} \geq 0, \forall k ; s_{n}^{x} \geq 0, \forall n ; s_{m}^{y} \geq 0, \forall m ; s_{i}^{b} \geq 0, \forall i
\end{aligned}
$$

Where $\left(x^{t, k^{t}}, y^{t, k^{t}}, b^{t, k^{t}}\right)$ represent the input and output vectors of commercial banks, $\left(g^{x}, g^{y}, g^{b}\right)$ represent directional vector of input reducing, expected output expansion, unexpected output decreased, $\left(s_{n}^{x}, s_{m}^{y}, s_{i}^{b}\right)$ represent the slack vector redundancy and output deficiency. The model measured the technical efficiency level of DMU: the input and output numerical relaxation bigger, show that the SBM value is greater, the farther away from the technology frontier; otherwise, invalid level is low, when slack vector is zero, the SBM value is zero, the measure of the commercial banks in the production frontier, that has the most technical efficiency. By solving the model, can relax vector optimal conditions $\left(s_{n}^{x}, s_{m}^{y}, s_{i}^{b}\right)$, which can be sources of inefficiency of technology decomposition.

\section{B. Definitions of Variable and Data Description}

Two approaches were applied to evaluate bank efficiency in the literature normally. One is the intermediation approach, which is based on the main function of the bank as a financial intermediary. Another is the production approach, which views banks as producers of financial services. Under the intermediation approach, this paper selected staff costs, total loans and fixed assets as input indicators, net profit for willing output, non-performing loans for unwilling output. It's noteworthy that the quality of loans (e.g., non-performing loans or problem loans) has received more emphasis in recent studies. Therefore, loan loss reserves are subtracted from total loans in order to ensure that this output is of comparable quality (e.g., Lensink et al., 2008). With respect to input variables, staff costs, total loans and fixed assets can be comprehensive reflect the banks in the human, financial, material resources, which are important indexes of the bank development. the output index of non-performing loans as the assessment of bank efficiency to avoid the neglect of quality aspects or may lead to a deviation, all units are for billion.

\section{ANALYSIS OF EMPIRICAL RESULT}

\begin{tabular}{|c|c|c|c|c|c|c|c|}
\hline Bank & 2007 & 2008 & 2009 & 2010 & 2011 & 2012 & average \\
\hline NBB & 1.000 & 1.000 & 0.732 & 1.000 & 1.000 & 0.884 & 0.936 \\
\hline NJB & 1.000 & 1.000 & 1.000 & 0.808 & 1.000 & 1.000 & 0.968 \\
\hline BJB & 1.000 & 1.000 & 1.000 & 1.000 & 1.000 & 1.000 & 1.000 \\
\hline PAB & 0.471 & 0.943 & 0.779 & 0.761 & 1.000 & 0.640 & 0.766 \\
\hline SPDB & 0.510 & 0.690 & 0.685 & 0.806 & 1.000 & 1.000 & 0.782 \\
\hline HXB & 0.347 & 0.332 & 0.371 & 0.498 & 0.548 & 0.644 & 0.457 \\
\hline CMB & 0.718 & 0.661 & 0.637 & 1.000 & 0.861 & 1.000 & 0.813 \\
\hline CMEB & 0.953 & 1.000 & 0.698 & 1.000 & 0.871 & 0.870 & 0.899 \\
\hline FXB & 1.000 & 1.000 & 1.000 & 1.000 & 1.000 & 1.000 & 1.000 \\
\hline CEB & 0.570 & 0.547 & 0.524 & 0.633 & 0.681 & 0.744 & 0.616 \\
\hline CITIC & 0.667 & 0.681 & 0.575 & 0.692 & 1.000 & 0.611 & 0.704 \\
\hline JTB & 0.768 & 0.706 & 0.649 & 0.694 & 0.721 & 0.705 & 0.707 \\
\hline ICBC & 0.737 & 0.707 & 0.961 & 0.742 & 1.000 & 0.791 & 0.823 \\
\hline $\mathrm{ABC}$ & 0.365 & 0.388 & 0.378 & 0.517 & 0.580 & 0.646 & 0.449 \\
\hline $\mathrm{CCB}$ & 0.697 & 0.671 & 0.778 & 0.710 & 0.886 & 0.695 & 0.740 \\
\hline $\mathrm{BC}$ & 0.722 & 0.573 & 0.601 & 0.652 & 1.000 & 0.807 & 0.726 \\
\hline nationwide & 0.720 & 0.744 & 0.711 & 0.782 & 0.884 & 0.815 & 0.776 \\
\hline $\begin{array}{c}\text { The big } \\
\text { four }\end{array}$ & 0.630 & 0.585 & 0.680 & 0.655 & 0.867 & 0.735 & 0.692 \\
\hline Joint-stock & 0.667 & 0.729 & 0.658 & 0.787 & 0.854 & 0.802 & 0.749 \\
\hline $\mathrm{CCB}$ & 1.000 & 1.000 & 0.911 & 0.936 & 1.000 & 0.961 & 0.968 \\
\hline
\end{tabular}

\section{A. The Technical Efficiency of Listed Commercial Banks and Comprehensive Analysis}

TABLE I. EVALUATION OF CHINESE LISTED COMMERCIAL BANKS EFFICIENCY RANKING

Note: ICBC(Industrial \& Commercial Bank of China), ABC(Agricultural Bank of China), $\mathrm{CCB}$ (China Construction Bank), BOC(Bank of China), CCB(City Commercial Banks), CCB(China Construction Bank), BOC(Bank of China), CCB(City Commercial Banks),
CITIC(China CITIC Bank), CEB(China Everbright Bank), HXB(Huaxia Bank), CMB(China Minsheng Bank), PAB(Pingan Bank), NBB(Ningbo Bank), NJB(Nanjing Bank), BJB(Beijing Bank), SPDB(Shanghai Pudong Devolopment Bank), CMEB(China Merchants Bank), FXB(Fujian Xingye Bank), JTB(Jiaotong Bank)

This paper will make preliminary research on the efficiency of each commercial bank firstly. Based on above analysis, method and data obtained, using the SBM model which considering unwilling output to measure the efficiency of commercial bank, the annual comprehensive efficiency of commercial banks can be obtained. After finishing, got the operating efficiency of 16 listed banks in each yearas, shown in table I. 
Firstly can be found in Table I, during 2007 to 2012, the operating efficiency of FXB and BJB are the highest, up to 1, which make up the frontier bank efficiency, while the efficiency of ABC is the lowest. The results are as follows:

(1) The efficiency of city commercial banks is the best. Table I shows, the efficiency of BJB, NJB and NBB made the top three during the study, achieving above 0.9. Analysis showed that the high efficiency of city commercial banks thanks to the flexible operation, market reaction on the external is more sensitive and rapid decision-making, they can timely to meet the urgent demand for funds of enterprises as well.

(2) Joint-stock commercial bank efficiency is generally better. From table I, among joint-stock banks, only the FXB presents the efficient, and remained stable trend absolutely, this means that the FBX both in the size of the company and in the management level are more reasonable. HXB efficiency is the lowest, only 0.457 , from the analysis of annual report, small assets scale, asset allocation is conservative and its nonperforming loans at a high level in the sample banks, leading to gap of its asset profitability and formation inevitably. SPDB has been in a rapid progress, and finally reach the efficiency frontier, in recent years, great progress has been made in SPDB, especially the profit ability is quite prominent; and SPDB has been committed to promote the staff efficiency ratio, then it has made the comprehensive efficiency better. PAB fluctuates greatly, this is mainly because of the SPDB write downs of 9.4billion of non-performing loans in 2008, the total profit increased nearly $800 \%$. CMB and CMEB market performance after the optimal ones, each have two years to reach the efficiency frontier. The other joint-stock banks efficiency is relatively stable, this mainly benefit the long period of reform in joint-stock commercial banks and business innovation.

(3) The large state-owned commercial banks efficiency showed a low level. In the large state-owned commercial banks, ICBC are prominent, but the efficiency of ABC is less than 0.5 nearly 6 years. Compared with other state-owned banks, the ICBC occupy the market opportunities early, grasped the highest point among banking. $\mathrm{ABC}$ is the latest as a joint-stock transformation among state-owned banks, profitability and operating efficiency is obviously lower than the other stateowned banks, The bank look over to agriculture business, business is too simple and the technology content is low. Although the big four has large scale, but hidden the fact that unit investment benefit is low. With the reform of state-owned commercial banks and the promote of the consciousness of competition, the state-owned banks and joint-stock banks efficiency gap is gradually narrowed.

\section{B. Decomposition of the Inefficiency of the Listed Commercial Banks}

This paper estimated the Chinese listed commercial banks annual comprehensive efficiency, and decompose the total uneffective rate, in order to further analyze which factor leads to inefficiency. Table II summarizes the average values of input, output, and No efficiency value to 16 commercial banks during 2007 to 2012.
TABLE II. Chinese Listed COMMERCIAL BANKS INVALID RATE DECOMPOSITION OVER THE PERIOD 2007-2012

\begin{tabular}{|c|c|c|c|c|c|c|}
\hline Bank & Gross & Staff & Total & fixed & Net & NPL \\
\hline loans & assets & profit & \\
\hline NBB & 0.111 & 0.032 & 0.002 & 0.044 & 0.000 & 0.034 \\
\hline NJB & 0.032 & 0.003 & 0.021 & 0.008 & 0.000 & 0.000 \\
\hline BJB & 0.000 & 0.000 & 0.000 & 0.000 & 0.000 & 0.000 \\
\hline PAB & 0.349 & 0.103 & 0.039 & 0.037 & 0.098 & 0.073 \\
\hline SPDB & 0.254 & 0.073 & 0.048 & 0.054 & 0.000 & 0.079 \\
\hline HXB & 0.454 & 0.102 & 0.016 & 0.071 & 0.181 & 0.085 \\
\hline CMB & 0.197 & 0.054 & 0.036 & 0.035 & 0.000 & 0.047 \\
\hline CMEB & 0.101 & 0.047 & 0.012 & 0.035 & 0.000 & 0.007 \\
\hline FXB & 0.000 & 0.000 & 0.000 & 0.000 & 0.000 & 0.000 \\
\hline CEB & 0.401 & 0.118 & 0.051 & 0.087 & 0.029 & 0.116 \\
\hline CITIC & 0.269 & 0.076 & 0.036 & 0.071 & 0.000 & 0.099 \\
\hline JTB & 0.304 & 0.095 & 0.010 & 0.086 & 0.035 & 0.076 \\
\hline ICBC & 0.222 & 0.062 & 0.000 & 0.081 & 0.004 & 0.075 \\
\hline ABC & 0.531 & 0.103 & 0.000 & 0.078 & 0.205 & 0.145 \\
\hline CCB & 0.304 & 0.103 & 0.000 & 0.071 & 0.009 & 0.122 \\
\hline NPLBC & 0.353 & 0.141 & 0.000 & 0.092 & 0.012 & 0.109 \\
\hline nationw & 0.223 & 0.070 & 0.017 & 0.053 & 0.036 & 0.067 \\
\hline ide & 0.038 & 0.012 & 0.008 & 0.017 & 0.000 & 0.011 \\
\hline The big & 0.303 & 0.102 & 0.000 & 0.081 & 0.058 & 0.113 \\
\hline
\end{tabular}

(1) It can be seen from table II, the invalid value is $24.3 \%$. From the selected indicators, the banking must reasonably reduce $7 \%$ staff costs, $1.7 \%$ loans and $5.3 \%$ fixed asset investment, furthermore, reduce $6.7 \%$ bad loans and increase $3.6 \%$ net profit to make sure the banking efficiency can be fully effective. The staff cost inefficiency is the biggest, accounting for $28.8 \%$ overall, and the big four staff inefficiency value accounted $54.26 \%$ to total efficiency, therefore, the big four banks still exist some problems in human resource management. 
(2) For big state-owned banks, the most prominent is the non-performing loans than other banks, It is 1.74 times that of the joint-stock banks, and 10 times that of the city commercial banks. According to the China Banking Regulatory Commission to preliminary statistics, the non-performing loans of Chinese banking are mostly concentrated in big state-owned banks, making up more than $30 \%$ of bad loans than others. Total loans on big four in the efficiency frontier, this is reasonable, because it shows that Chinese state-owned commercial bank assets occupy absolute proportion in the whole banking and most of the financial resources, can obtain lower financing costs. On the contrary, although the joint-stock and city commercial banks there is no special preferential policies from country, but they have no policy burden, mainly rely on their own profit to write down non-performing assets and bad debt, it shows more cautious attitude on the loan risk management.

For joint-stock commercial banks, invalid source is mainly reflected on the total loan, this factors invalid rate is 1.65 times that of national average. This phenomenon may be attributed to the joint-stock commercial bank's unceasing development, the bank funds has grown stronger, but the joint-stock banks scale is smaller than the big four banks, they usually set up the outlets in the local of high economies levels, making loan amount is insufficient.

On the city commercial banks, invalid rate of fixed assets value is relatively large, this is due to start to support the Chinede city commercial banks to set up a branch from 2006, the Bank of Beijing was the first to achieve coverage of domestic economy developed area. Loose monetary policy contributed to the city commercial bank cross business expansion frenzy, only in 2010 , it rose nearly $40 \%$, but the problem that lack of personnel and internal management problemsare prominent. On the other hand the local government adding to the city commercial bank's expansion, the regional government pursuit of GDP and achievement of digital sidely, not only to introduce the foreign banks in local, but also encourages local city commercial banks to open branches in other places, and enter the stock market, forthermore, take this as the regional economic development planning to promote.

\section{CONCLUSIONS AND SUGGESTIONS}

Ignore the non-performing loans will overestimate the banking efficiency, in order to make up this shortcoming, this paper selects the non-performing loans as unwilling output, use the SBM directional distance function model to measure the efficiency of 16 Chinese listed commercial banks during the period 2007-2012 and factor decomposition efficiency.

The empirical findings are briefly summarized as follows: During the study, the Chinese Listed Commercial Banking technical efficiency table can be seen, the best is Industrial bank and Beijing bank efficiency, they has reached frontier bank efficiency, while the Agricultural bank efficiency is lowest. Analysis the decomposition of the invalid rate further, staff costs Influence is the maximum, accounting for the overall proportion of $28.8 \%$; the followed invalid rate is nonperforming loans by $27.6 \%$, this can not be ignored.

Based on the above empirical analysis, combining the current situation of management and development of commercial banks in China, we put forward some policy suggestions as follows: firstly, Chinese commercial banks should pay attention to the service quality and enhancing the local relations, at the same time, paying more attention to their own business development, and strive to do business innovation; secondly, Chinese banks should merge overstaffed institutions, reduce redundant staff, forthermore, from the panel data, high non-performing assets in the big four commercial banks in China is still very serious threat; the last, it's time to banks rely on their own ability to eat. To sum up in a word, improve customer trust, loyalty and reputation, is the foundation of development of bank industry in the future.

\section{ACKNOWLEDGEMENT}

This paper is one of the research achievements of Soft Science Research Base in Hebei Province.

\section{REFERENCES}

1] Assaf, A.G., Barros, C.P., Matousek, R., 2011. Productivity and efficiency analysis of Shinkin banks: evidence from bootstrap and Bayesian approaches. Journal of Banking and Finance 35, 331-342.

[2] Barros, C.P., Peypoch, N., Williams, J., 2010. A note on productivity change in European cooperative banks: the Luenberger indicator approach. International Review of Applied Economics 24, 137-147.

[3] Berger, A.N., Hasan, I., Zhou, M., 2010. The effects of focus versus diversification on bank performance: evidence from Chinese banks. Journal of Banking and Finance 34, 1417-1435.

[4] Chambers, R.G., Chung, Y., Fe, R., 1998. Profit, directional distance functions, and Nerlovian efficiency. Journal of Optimization Theory and Applications 98, 351-364.

[5] Kerstens, K., Mounir, A., Van de Woestyne, I., 2011. Geometric representation of the mean-variance-skewness portfolio frontier based upon the shortage function. European Journal of Operational Research 210, 81-94.

[6] Lensink, R., Meesters, A., Naaborg, I., 2008. Bank efficiency and foreign ownership: do good institutions matter? Journal of Banking and Finance 32, 834-844.

[7] Matthews, K., Zhang, N., 2010. Bank productivity in China 1997-2007: measurement and convergence. China Economic Review 21, 617-628.

[8] Sun, L., Chang, T.-P., 2011. A comprehensive analysis of the effects of risk measures on bank efficiency: evidence from emerging Asian countries. Journal of Banking and Finance 35, 1727-1735.

[9] Zhang Jianhua.DEA Method on Efficiency Study of Chinese Commercial Banks and the Positivist Analysis from 1997 to 2001[J].Journal of Finance(in Chinese),2003,(3):11-25.

[10] Zeng Jiang-hong,Chen Di-yu.Efficiency Research on debt financing of SMEs Based on DEA[J].Economic Theory and Business Management(in Chinese),2008,(1):50-53.

[11] He Feng.The Study on the Nexus Between Firm Efficiency and Firm Value Basing on DEA and SFA An Empirical Analysis on Chinese and Japanese Listed Companies in Electricity Machinery Industry[J].Chinese Journal of Management,2009,6(7):873-878.

[12] Cai Yue-zhou,Guo Mei-jun.Empirical Analysis about Total Factor Productivity of Listed Commercial Bank in China[J].Economic Research Journal(in Chinese),2009,44(9):52-65.

[13] Wang Bing,Zhu Ning. Research on Chinese listed commercial bank efficiency and the total factor productivity of bad loan constraint[J]. Economic Research Journal(in Chinese),2011, (1):110-130.

[14] Milind Sathye, "Efficiency of banks in a developing economy: The case of India”, European Journal of Operational Research, Vol. 148, Issue 3, pp. 662-671, August 2003.

[15] C. Homburg, "Using data envelopment analysis to benchmark activities", International Journal of Production Economics, 2001, Vol.73, pp. 51-58. 